\title{
Influence of foliar spray with some calcium sources on flowering, fruit set, yield and fruit quality of olive Kalmata and Manzanillo cultivars under salt stress
}

\author{
Eman S. El-Hady ${ }^{*}$ (D, Mohamed A. Merwad, Mohamed F. M. Shahin and Laila F. Hagagg
}

\begin{abstract}
Background: This work was carried out through 2017 and 2018 seasons on Kalmata and Manzanillo olive cultivars. Trees were 15 years old, grown in sandy soil and planted at $5 \times 5 \mathrm{~m}$ apart irrigated with saline water through drip irrigation system. This investigation aimed to improve flowering, fruit set, yield and fruit quality of the tow olive cultivars. Trees were sprayed with calcium at $0.5 \%$ as calcium chloride (21\% Ca) and chelated calcium.

Results: The results revealed that there were significant differences with calcium source treatment regarding number of inflorescences/shoot, no. of total flowers/inflorescences, sex expression, initial fruit set, final fruit set (\%) and yield/ $\mathrm{kg}$ (tree) and decreasing fruit drop (\%) of olive oil Kalmata and Manzanillo cultivars compared with unsprayed in both seasons.

Conclusions: Results proved that olive trees sprayed at the end of December with $0.5 \%$ calcium as chelated calcium was the promising treatment for good flowering, fruit set, yield and fruit quality.

Keywords: Olive (Olea europaea L.), Kalamata, Manzanillo, Calcium chloride, Chelated calcium, Flowering, Fruit set, Yield and fruit quality
\end{abstract}

\section{Background}

Olive (Olea europaea L.) considered is one of the oldest cultivated trees in the history of the world about 8000 years ago. In Egypt, table olive cultivars play an important function in economics of the growers where most of the olive production is consumed as pickling products. Plant growth and fruit production are all expected to be influenced by levels of available nutrients and soil properties. Flowering and fruit set are the main processes influencing the productivity of fruit trees that are especially important for the olive, in which there is a clearly accurate relationship between vegetative and reproductive growth (Lavee 2006). Thereby, poor fruit

*Correspondence: eman_elhady_79@yahoo.com

Pomology Department, Agricultural and Biological Research Division, National Research Centre, 33 El Buhouth St., Dokki, Giza 12622, Egypt set, high fruit shedding and consequently poor yields are considered critical factors for growing table cultivars.

Olive trees existing in Mediterranean climate are almost grown in semiarid regions, where rainfall considered rare and irregular which responsible of low yields. Olive trees mainly grown around the Mediterranean Basin have been conventional cultivated in dry lands (Orgaz and Fereres 2004), lack of water requirements for the growth and productivity of olive tree cultivated in dry lands leading to the use of low-quality water resources. Olive trees are considered moderately tolerant to salinity (Maas and Hoffman 1977; FAO 1985; Rugini and Fedeli 1990). For that reason, high concentrations of salts in irrigation water cause a decrease in nutrient that may be due to both dysfunctions of membrane selectivity and ionic competitive interactions (Kozlowski 1997) which led to ionic imbalance (Zhu 
2001; Munns 2002). The accumulation of $\mathrm{Na}^{+}$and $\mathrm{Cl}^{-}$ ions to toxic levels in plants decrease the absorption of potassium, magnesium and calcium (Daas-Ghrib et al. 2011; Farissi et al. 2014). $\mathrm{Ca}^{2+}$ is also assumed to play an important role in retention mechanisms and sodium exclusion, which may be considered responsible for survival under salt stress conditions (Melgar et al. 2006; Tattini and Traversi 2008).

Calcium element is considered a secondary plant nutrient and acts as signaling molecule and plays a very important function in nutrition and plant growth, as well as in cell wall precipitation. $\mathrm{Ca}^{2+}$ element considered a multifunctional nutrient in plant physiology, which influences the availability nutrient and its uptake and has a role raising strength and thickness of cell wall. $\mathrm{Ca}^{2+}$ element levels affect the strength of plant stem and fruit quality. $\mathrm{Ca}^{2+}$ element considered a crucial regulator of growth and development in plants. Calcium ion sharing in many growing processes and nearly involves in all plant development aspects (Harper et al. 2004; Hetherington and Brownlee 2004; Hirschi 2004; Reddy and Reddy 2004; Bothwell and Ng 2005).

$\mathrm{Ca}^{2+}$ element renowned by its protective function in most abiotic stresses: salt stress drought, heat, cold, and heavy metals (Khan et al. 2010; Liu et al. 2014). $\mathrm{Ca}^{2+}$ is found to be crucial in altering the ion selectivity absorption and in enhancing salt tolerance in many species (Rengel 1992; Zhu 2003). Under salt stress, plant cells either accumulate calcium or releasing intracellular cytosolic calcium, which working as a signaling molecule and adjust a range of physiological processes to modify salt stress (Kader et al. 2007; Kader and Lindberg 2008, 2010). Also, it is known that calcium chained the sodium element entering plant cells and this contributes to reducing the negative effects of salinity (Kader and Lindberg 2008; Hussain et al. 2010). Additionally, calcium considered essential element for potassium/sodium and calcium/sodium selectivity and reducing the negative effects of salinity by regulating ion transport in plants (Renault 2005). Application of calcium alleviated adverse effects of salinity on plants, sodium formed competition with calcium ion on the cell wall, therefore high levels of calcium protected cell membrane from adverse effects of salinity (Busch 1995). Various studies indicate that $\mathrm{Ca}^{2+}$ reduced peroxidation of lipid, increased activity of antioxidant enzyme and improve osmotic adjustment of cell membranes (Hernandez et al. 2003; Amor et al. 2010). Whereas $\mathrm{Ca}^{2+}$ at moderate concentration reducing oxidative damage produced by sodium chloride in Cakile maritime (Amor et al. 2010) and $\mathrm{Ca}^{2+}$ at high concentration improved salt tolerance in Nitraria tangutorum (Liu et al. 2014). These reports show that calcium has different effects in inducing salt stress tolerance that may depend upon the species or concentration of calcium applied.

Plant roots absorb calcium from the soil solution in the form of $\mathrm{Ca}^{2+}$ ions (Clarkson 1993; White 2001) Ca mineral, relatively insoluble in soil in this state and considered a leachable nutrient. Which reduce the calcium uptake by plants. With regard to uptake and mobility of $\mathrm{Ca}$ in plants, $\mathrm{Ca}$ uptake is passive which means not require energy input. Ca mobility occurs fundamentally in the xylem, flow with the movement of water. Thus, uptake of Ca related directly to the rate of transpiration in plant. Accumulation of salinity might also limiting mobility of calcium in plants which led to deficiency of calcium due to its effect on decreasing uptake of water by the plant. Deficiency of Ca will appear in younger leaves and in fruits, due to its low rate of transpiration. Thence, it is necessary to have a constant supply of calcium to continue growing. (Kadir 2004).

However, efficiency of foliar application with $\mathrm{Ca}$ depends on the source of $\mathrm{Ca}$ and applied dosage. In this regard, foliar application of calcium chloride was more efficient than that of calcium oxide and chelate calcium (Almeida et al. 2016). $\mathrm{CaCl}_{2}$ is highly soluble in water and is deliquescent. It can be used on plants as a source of $\mathrm{Ca}$ and $\mathrm{Cl}$ and plays an important role in photosynthesis and other cellular processes (Wahid et al. 2007; Rab and Haq 2012).

The leaf fertilizers which an inorganic mineral structure hardly diffuses from the leaf surface into the plant because of high weight molecular structure. Chelating agents describe a kind of organic chemical complex that can encapsulate certain metallic salts and then release these metallic salts slowly to become available for up take by plants (Marschner 1995; Zocchi and Mignani 1995).

Thence synthetic portent like EDTA (ethylene diamine tetra acetic acid) and EDDHA (ethylene diamino-hydroxyphenylacetic acid) which has the ability of making strong chelate is almost used in plantgrowing medium. Foliar fertilizers as chelate should be easily absorbed by the plants rapidly transported and should be easily release their ions to affect the plant (Zocchi and Mignani 1995). Natural chelates as midmolecular weight compounds like amino acids that have long organic chains diffuse easily to cell cytoplasm according to their chemical structure. These chelates are not phytotoxic to plants (Ferguson and Drobak 1988).

The current study was therefore initiated to investigate the influence of foliar application of calcium chloride and calcium chelate on the yield and fruit quality characteristics olive Kalmata and Manzanillo cultivars. 


\section{Methods}

The present study was conducted during two successive seasons, 2017 and 2018, on 15-year-old olive trees Kalamata and Manzanillo cvs. grown in a private orchard located at Ismailia governorate, Egypt. The trees spaced $5 \times 5 \mathrm{~m}$ apart (168 trees/feddan) in a sandy soil (Table 1 ). The trees received the same cultural practices according to the recommendations of the Ministry of Agriculture. The trees irrigated by drip irrigation system depending on wells in irrigation (Table 2). The trees were almost similar in vigor, free from any visible pathogenic symptoms and at the same bearing phase. Complete block randomized design was applied. Three treatments were applied in five replicates (one tree for each replicate); all of the 15 trees conducted in this study were vigorous and similar in growth and canopy.

\section{Experimental design}

The treatments will be arranged in a randomized complete block design (RCBD), the experiment contained three treatments were applied in five replicates (one tree for each replicate). The normal horticulture practices that used in the farm were applied to all Kalamata and Manzanillo olive trees.

\section{Experimental material}

1 Calcium chloride is a chemical compound with the formula $\mathrm{CaCl}$. It is a common substance found in rocks as the minerals calcite and aragonite (most notably as limestone, which is a type of sedimentary rock built mainly of calcite).

2 Chelated calcium: the chelating agents used in this experiment were natural chelates as mid-molecular weight compounds like amino acids that have long organic chains diffuse easily to cell cytoplasm according to their chemical structure.

\section{Treatments}

Effect of spraying with two sources of calcium on two olives (Kalamata and Manzanillo cvs), this experiment included three treatments as follows:

T0: Control.

$\mathrm{T} 1: \mathrm{CaCl}(0.5 \%)$.

T2: Calcium chelate ( $0.5 \%)$.

Table 1 Effect of foliar spray with some calcium sources on flowering of olive Kalmata and Manzanillo cultivars

\begin{tabular}{|c|c|c|c|c|c|c|}
\hline & \multicolumn{2}{|c|}{ No. of inflorescences/shoot } & \multicolumn{2}{|c|}{ No. of total flowers/inflorescences } & \multicolumn{2}{|c|}{ Sex expression } \\
\hline & 2017 & 2018 & 2017 & 2018 & 2017 & 2018 \\
\hline \multicolumn{7}{|l|}{ Kalmata } \\
\hline Control & $11.00 \mathrm{~b}$ & $9.00 \mathrm{~b}$ & $17.50 \mathrm{~b}$ & $6.33 b$ & $70.22 b$ & $44.17 b$ \\
\hline $\mathrm{CaCl}_{2}$ & $16.50 \mathrm{a}$ & $13.83 a$ & $23.50 a$ & $21.50 \mathrm{a}$ & $77.96 a$ & $76.56 a$ \\
\hline Chelated Ca & $15.75 \mathrm{a}$ & $14.87 a$ & $21.75 a$ & $21.67 a$ & $79.98 a$ & $78.90 a$ \\
\hline \multicolumn{7}{|l|}{ Manzanillo } \\
\hline Control & $10.56 a$ & $7.23 b$ & $20.57 a$ & $8.57 b$ & $61.77 b$ & $53.62 \mathrm{C}$ \\
\hline $\mathrm{CaCl}_{2}$ & $12.58 \mathrm{a}$ & $13.03 a$ & $23.33 a$ & $12.33 a$ & $63.14 a b$ & $59.00 \mathrm{~b}$ \\
\hline Chelated Ca & $11.33 a$ & $12.43 a$ & $23.93 a$ & $13.67 a$ & $73.75 a$ & $66.33 a$ \\
\hline
\end{tabular}

Table 2 Effect of foliar spray with some calcium sources on fruit set and yield of olive Kalmata and Manzanillo cultivars

\begin{tabular}{|c|c|c|c|c|c|c|c|c|}
\hline & \multicolumn{2}{|c|}{ Initial fruit set (\%) } & \multicolumn{2}{|c|}{ Final fruit set (\%) } & \multicolumn{2}{|c|}{ Fruit drop (\%) } & \multicolumn{2}{|c|}{ Yield (kg/tree) } \\
\hline & 2017 & 2018 & 2017 & 2018 & 2017 & 2018 & 2017 & 2018 \\
\hline \multicolumn{9}{|l|}{ Kalmata } \\
\hline Control & $25.63 b$ & $32.57 a$ & $16.07 b$ & $22.89 a$ & $31.77 a$ & $34.34 a$ & $19.41 c$ & $24.00 \mathrm{c}$ \\
\hline $\mathrm{CaCl}_{2}$ & $34.26 a$ & $35.83 a$ & $24.55 a$ & $23.52 a$ & $23.85 b$ & $29.72 a b$ & $41.33 b$ & $33.67 b$ \\
\hline Chelated Ca & $37.26 a$ & $37.14 \mathrm{a}$ & $25.10 \mathrm{a}$ & $26.55 a$ & $25.39 b$ & $28.61 b$ & $50.67 a$ & $57.67 a$ \\
\hline \multicolumn{9}{|l|}{ Manzanillo } \\
\hline Control & $28.91 b$ & $26.94 b$ & $17.95 c$ & $14.01 b$ & $37.93 c$ & $48.60 \mathrm{a}$ & $24.00 \mathrm{~b}$ & $19.00 \mathrm{~b}$ \\
\hline $\mathrm{CaCl}_{2}$ & $37.50 a$ & $69.71 a$ & $22.19 b$ & $29.66 a$ & $48.39 a$ & $24.60 \mathrm{~b}$ & $45.00 \mathrm{a}$ & $27.38 a$ \\
\hline Chelated Ca & $42.06 a$ & $80.12 \mathrm{a}$ & $27.53 a$ & $32.64 a$ & $41.16 b$ & $22.07 b$ & $45.33 a$ & $31.56 \mathrm{a}$ \\
\hline
\end{tabular}


Calcium chloride $(0.5 \%)$ and calcium chelate $(0.5 \%)$ were applied as foliar spray at the end of December. Calcium chloride and calcium chelate were prepared from analytical grade chemicals. A back-held spray pump was used for foliar application of the chemicals. After each treatment, the pump was washed thoroughly. A teaspoon of commercial washing powder was added as a wetting agent. Tap water containing a comparable amount of wetting agent was sprayed on the plants in the controlled treatment. All foliar spraying was carried out early in the morning.

The number of flower clusters per plant, number of fruits per cluster, and number of fruits per plant were determined for three plants in the middle row of the plot. For this purpose, the number of flower clusters per plant, number of fruits per cluster, and number of fruits per plant were counted and divided by the total number of plants. The total yield for each treatment was calculated by weighing the fruit picked in each plot and converting the weight to yield per acre. The average fruit weight was estimated by weighing 100 fruits in each treatment, with the help of an electronic balance measuring in grams to the third decimal place, and then converting to average fruit weight.

\section{Measurements}

1 Flowering parameters:

- Ten (1-year-old) shoots were chosen at random and labeled on each tree for each season's during full bloom (late April) to count the total number of inflorescences per shoot and number of flowers per inflorescences.

- Sex expression: the percentage of perfect flowers to the total number of flowers was calculated in previously the thirty inflorescences at balloon stage for each replicate.

- Initial fruit set (\%): Fruit set was calculated after 21 days from full blooming, Mofeed (2002).

- Final fruit set (\%): Fruit set was calculated at the beginning phase of ripening.

- Fruit drop (\%): Fruit drop was measured for the selected trees by chosen 4 small branches/tree in the 4 directions, we was wrap the branches in a net bag and we was collected the drop fruits every 15 days and count it. During the last observation, we counted the number of olives still on the branch.

- Yield ( $\mathrm{kg} /$ tree): average yield $(\mathrm{kg})$ per tree was recorded at harvesting date for every replicate tree from each treatment.
2 Fruit parameters:

Hundred fruits per each tree were randomly selected and used to determine the following physical characteristics:

lower-alpha Fruit weight (g): The average fruit weight (g) was determined by weighing the sample of each studied tree.

1 Fruit volume $\left(\mathrm{cm}^{3}\right)$ : Average fruit volume $(\mathrm{ml})$ was determined from the volume of water displaced method.

$2 \mathrm{Pulp} / \mathrm{seed}$ ratio: stones were extracted to determine stone weight $(\mathrm{gm})$, flesh/fruit weight and flesh/stone ratio.

3 Oil \%: Oil content percentage in dry weight was extracted by Soxelt apparatus from the dry fruit samples using petroleum ether (60-80) as a solvent for $16 \mathrm{~h}$ according to the method described by A.O.A.C (1995).

\section{Statistical analysis}

All obtained data during both 2017 and 2018 experimental seasons were subjected to analysis of variances (ANOVA) according to Snedecor and Cochran (1980) using MSTAT program. Least significant ranges (LSR) were used to compare between means of treatments according to Duncan (1955) at probability of 5\%.

\section{Results}

Data in Table 1 indicate that, there were significant differences with calcium source and control treatment regarding number of inflorescences/shoot, No of total flowers/ inflorescences and Sex expression of olive Kalmata and Manzanillo cultivars than unsprayed in both seasons.

Concerning Kalmata cultivar, sprayed trees with $\mathrm{CaCl}_{2}$ recorded the highest values of number of inflorescences/ shoot (16.50) and No of total flowers/inflorescences (23.50) in the 1st season, while sprayed with Chelated Ca recorded the highest values of number of inflorescences/ shoot (14.87) and No of total flowers/inflorescences (21.67) in the 2nd season and Sex expression (79.98 and $78.90)$ in both season against (11.00 and 9.00) number of inflorescences/shoot, (17.50 and 6.33) No of total flowers/inflorescences and (70.22 and 44.17) Sex expression for control treatment in the 1st and 2nd seasons, respectively.

As for Manzanillo cultivar, such data in the same Table 1 showed that, in general treated trees with chelated $\mathrm{Ca}$ recorded the highest values of highest values of No of total flowers/inflorescences (23.93 and 13.67) and Sex expression (73.75 and 66.33). While sprayed trees with $\mathrm{CaCl}_{2}$ recorded the highest values of No of 
inflorescences/shoot (12.58 and 13.03) against (10.56 and 7.23) number of inflorescences/shoot, (20.57 and 8.57) No of total flowers/inflorescences and (61.77 and 53.62) Sex expression in the 1st and 2nd seasons, respectively.

Results in Table 2 showed that foliar application of both Ca source were led to significant increases in initial fruit set, final fruit set (\%), Fruit drop (\%) and yield/kg (tree) of olive Kalmata and Manzanillo cultivars than control treatment in both season, except initial fruit set, final fruit set (\%) in the 1st season for Kalmata cultivar.

As for Kalmata cv. The data show that, sprayed trees with Chelated Ca gave the highest values of initial fruit set \% (37.26 and 37.14), yield/tree (50.67 and $57.67 \mathrm{~kg} /$ tree) in both seasons and final fruit set $(25.10 \%)$ in the 1 st season and lowest fruit drop in the 2nd season (28.61\%) against (25.63 and 32.57) initial fruit set, (16.07 and $22.89 \%$ ) Final fruit set (\%), (19.41 and 24.00) yield $\mathrm{kg} /$ tree and highest fruit drop (31.77 and 34.34\%) in the 1st and 2nd seasons, respectively.

Also, sprayed Manzanillo tree with Chelated Ca was the best treatment for increasing initial fruit set, final fruit set (\%) and yield $/ \mathrm{kg}$ (tree) and decreasing fruit drop (\%) than sprayed with $\mathrm{CaCl}_{2}$ or control treatments.

Data in Table 3 indicated that, sprayed olive trees with different source of $\mathrm{Ca}$ had significant effect on fruit weight, fruit volume, pulp/seed ratio and oil percentage in fruit in both Kalmata and Manzanillo cultivars than unsprayed tree in the two tested seasons, except fruit weight with Kalmata cultivar in both seasons.

Treated Kalmata cv. with $\mathrm{CaCl}_{2}$ gave the highest values of fruit volume $\left(5.40\right.$ and $\left.5.27 \mathrm{~cm}^{3}\right)$ and oil percentage (47.60 and $40.33 \%)$, while sprayed with Chelated $\mathrm{Ca}$ gave the highest values of Pulp/seed ratio (5.78 and 5.85) against fruit volume $\left(4.87\right.$ and $\left.4.68 \mathrm{~cm}^{3}\right)$, Pulp/seed ratio (2.36 and 2.44) and oil percentage in fruit (40.47 and $35.60 \%$ ) for control treatment in the 1st and 2nd seasons, respectively.
As for Manzanillo cv., control treatment (unsprayed trees) gave the highest values of fruit weight and fruit volume in both seasons, while sprayed trees with Chelated $\mathrm{Ca}$ gave the maximum percentage of oil in fruit (49.27 and 50.67\%) against (32.67 and 37.00\%) for unsprayed trees, in addition, treated trees with $\mathrm{CaCl}_{2}$ recorded (43.87 and $44.53 \%$ in the 1 st and 2 nd seasons, respectively.

\section{Discussion}

The beneficial effect of calcium in increasing fruit set might be due to the higher availability of photosynthesis, and these chemicals are also associated with hormone metabolism which promotes synthesis of auxin, essential for fruit set and growth (Kazemi 2014).

\section{Conclusions}

Results proved that olive trees sprayed at the end of December with $0.5 \%$ calcium as chelated calcium was the promising treatment for good flowering, fruit set, yield and fruit quality.

\section{Abbreviations \\ Ca: Calcium; $\mathrm{Ca}^{+}$: Calcium ion.}

\section{Acknowledgements}

Not applicable.

\section{Authors' contributions}

This work was carried out in collaboration between all authors. Author LFH designed the study, wrote the protocol, managed the field works and reviewed the final draft of manuscript; Author MFMSh managed the literature searches, tabled the field data for the statistical analyses, prepared the samples for analyses and wrote the first draft of the manuscript. Author MMA participated in the field works, collected field samples and tabled the data for statistical analyses. Author ESEl conducted the field applications, tabled the field data for the statistical analyses, prepared the samples for analyses, conducted the physical and chemical analyses, performed the statistical analyses. All authors have read and approved the manuscript.

Funding

Not applicable.

Table 3 Effect of foliar spray with some calcium sources on fruit quality and oil percentage of olive Kalmata and Manzanillo cultivars

\begin{tabular}{|c|c|c|c|c|c|c|c|c|}
\hline & \multicolumn{2}{|c|}{ Fruit weight (g) } & \multicolumn{2}{|c|}{ Fruit volume $\left(\mathrm{cm}^{3}\right)$} & \multicolumn{2}{|c|}{ Pulp/seed ratio } & \multicolumn{2}{|c|}{ Oil (\%dry W) } \\
\hline & 2017 & 2018 & 2017 & 2018 & 2017 & 2018 & 2017 & 2018 \\
\hline \multicolumn{9}{|l|}{ Kalmata } \\
\hline Control & $5.19 a$ & $4.87 a$ & $4.87 \mathrm{~b}$ & $4.68 b$ & $2.36 \mathrm{c}$ & $2.44 b$ & $40.47 b$ & $35.60 \mathrm{~b}$ \\
\hline $\mathrm{CaCl}_{2}$ & $5.42 \mathrm{a}$ & $5.52 \mathrm{a}$ & $5.40 \mathrm{a}$ & $5.27 a$ & $4.16 b$ & $5.44 a$ & $47.60 \mathrm{a}$ & $40.33 a$ \\
\hline Chelated Ca & $5.24 a$ & $5.41 \mathrm{a}$ & $5.06 a$ & $4.99 a$ & $5.78 \mathrm{a}$ & $5.85 a$ & $47.53 a$ & $39.13 a$ \\
\hline \multicolumn{9}{|l|}{ Manzanillo } \\
\hline Control & $4.87 a$ & $5.54 a$ & $4.30 \mathrm{a}$ & $5.20 \mathrm{a}$ & $3.52 \mathrm{C}$ & $2.68 b$ & $32.67 c$ & $37.00 c$ \\
\hline $\mathrm{CaCl}_{2}$ & $4.13 b$ & $4.27 \mathrm{~b}$ & $3.82 \mathrm{~b}$ & $4.12 b$ & $4.35 b$ & $3.57 a$ & $43.87 b$ & $44.53 b$ \\
\hline Chelated Ca & $4.49 a b$ & $4.50 \mathrm{~b}$ & $4.20 a b$ & $4.23 b$ & $4.97 a$ & $2.86 a b$ & $49.27 a$ & $50.67 a$ \\
\hline
\end{tabular}




\section{Availability of data and materials}

The datasets generated and/or analyzed during the current study are included in this published study.

\section{Ethics approval and consent to participate}

Not applicable.

\section{Consent for publication}

Not applicable.

\section{Competing interests}

The authors declare that they have no competing interests.

Received: 10 May 2020 Accepted: 13 November 2020

Published online: 27 November 2020

\section{References}

A. O. A. C. (1995) Association of Official; Agricultural Chemists

Almeida PH, Mógor ÁF, Ribeiro AZ, Heinrichs J, Amano E (2016) Increase in lettuce (Lactuca sativa L.) production by foliar calcium application. Aust J Basic Appl Sci 10:161-167

Amor NB, Megdiche W, Jiménez A, Sevilla F, Abdelly C (2010) The effect of calcium on the antioxidant systems in the halophyte Cakile maritima under salt stress. Acta Physiol Plant 32:453-461

Bothwell JHF, Ng CK-Y (2005) The evolution of $\mathrm{Ca}^{2+}$ signalling in photosynthetic eukaryotes. New Phytol 166:21-38

Busch DS (1995) Calcium regulation in plant cell and its role in signaling. Ann Rev Plant Physiol Mol Biol 46:95-122

Clarkson DT (1993) Roots and the delivery of solutes to the xylem. Philos Trans R Soc B 341:5-17

Daas-Ghrib C, Gharbi F, Kchaou R, Rejeb S, Hanchi B, Rejeb MN (2011) Salinity and mineral nutrition of two eucalyptus species. Eur J Sci Res 55:314-322

Duncan DB (1955) Multiple ranges and multiple tests. Biometrics 11:1-24

FAO (Food and Agriculture Organization) (1985) Water quality for agriculture. FAO Irrigation and Drainage Paper 29, Rome, Italy

Farissi M, Faghire M, Bargaz A, Bouizgaren A, Makoudi B, Ghoulam C (2014) Growth, nutrients concentrations, and enzymes involved in plants nutrition of alfalfa populations under saline conditions. J Agric Sci Technol 16:301-314

Ferguson IB, Drobak BK (1988) Calcium and the regulation of plant growth and senescence. Hortic Sci 2:262-266

Harper JF, Breton G, Harmon A (2004) Decoding $\mathrm{Ca}^{2+}$ signals through plant protein kinases. Annu Rev Plant Biol 55:263-288

Hernandez JA, Aguilar AN, Portillo B, Gomez EL, Beneyto JM, Garcia-Legaz MF (2003) The effect of calcium on the antioxidant enzymes from salt-treated loquat and anger plants. Funct Plant Biol 130:1127-1137

Hetherington AM, Brownlee C (2004) The generation of $\mathrm{Ca}^{2+}$ signals in plants. Annu Rev Plant Biol 55:401-427

Hirschi KD (2004) The calcium conundrum. Both versatile nutrient and specific signal. Plant Physiol 136:2438-2442

Hussain K, Nisar MF, Majeed A, Nawaz K, Bhatti KH, Afghan S, Shahazad A Zia-ul-Hassnian S (2010) What molecular mechanism is adapted by plants during salt stress tolerance? Afri J Biotechnol 9:416-422

Kader MA, Lindberg S (2008) Cellular traits for sodium tolerance in rice (Oryza sativa L.). Plant Biotechnol 25:247-255

Kader MA, Lindberg S (2010) Cytosolic calcium and pH signaling in plants under salinity stress. Plant Sig Behav 5:233-238

Kader MA, Lindberg S, Seidel T, Golldack D, Yemelyanov V (2007) Sodium sensing induces different changes in free cytosolic calcium concentration and
$\mathrm{pH}$ in salt tolerant and -sensitive rice (Oryza sativa) cultivars. Physiol Plant 130:99-111

Kadir SA (2004) Fruit quality at harvest of'Jonathan' apple treated with foliar applied calcium chloride. J Plant Nutr 27:1991-2006

Kazemi M (2014) Influence of foliar application of iron, calcium and zinc sulfate on vegetative growth and reproductive characteristics of strawberry cv. 'pajaro. Trakia. J Sci 1:21-26

Khan MN, Siddiqui MH, Mohammad F, Naeem M, Masroor M, Khan A (2010) Calcium chloride and gibberellic acid protect linseed (Linum usitatissimum L.) from $\mathrm{NaCl}$ stress by inducing antioxidative defense system and osmoprotectant accumulation. Acta Physiol Plant 32:121-132

Kozlowski TT (1997) Responses of woody plants to flooding and salinity. Tree Physiol Monogr 1:1-29

Lavee S (2006) Biennial bearing in olive (Olea europaea L.). Olea 25:5-13

Liu B, Luo C, Li X, Gray L, Zhang F, Liu M (2014) Research on the threshold of aluminum toxicity and the alleviation effects of exogenous calcium, phosphorus, and nitrogen on the growth of Chinese fir seedlings under aluminum stress. Commun Soil Sci Plant 45:126-139

Maas EV, Hoffman GJ (1977) Crop salt tolerance-current assessment. J Irrig Drain Div 103:115-134

Marschner H (1995) Mineral nutrition of higher plants, 2edn. Academic Press, London

Melgar JC, Benlloch M, Fernández-Escobar R (2006) Calcium increases sodium exclusion in olive plants. Sci Hortic 109:303-305

Mofeed AS (2002) Effect of olive mill wastewater on young hydroponically grown tomato plants. J Appl Bot 78:25-31

Munns R (2002) Comparative physiology of salt and water stress. Plant Cell Environ 25:239-250

Orgaz F, Fereres E (2004) Riego. In: Barranco D, Fernandez-Escobar R, Rallo L (eds) El cultivo del olivo. Mundi-Prensa, Madrid, pp 269-288

Rab A, Haq I (2012) Foliar application of calcium chloride and borax influences plant growth, yield and fruit. Turk J Agric 36:695-701

Reddy VS, Reddy ASN (2004) Proteomics of calcium-signaling components in plants. Phytochemistry 65:1745-1776

Renault S (2005) Response of red-osier dogwood (Cornus stolonifera) seedlings to sodium sulphate salinity: effects of supplemental calcium. Physiol Plant 123:75-81

Rengel Z (1992) The role of calcium in salt toxicity. Plant Cell Environ 15:625-632

Rugini E, Fedeli E (1990) Olive as an oilseed crop. In: Bajaj YPS (ed) Legumes and oilseed crops. Springer, Berlin, pp 593-641

Snedecor GA, Cochran WG (1980) Statistical methods. Oxford and J. B. H. Bub Com., 7th edn. State University Press, lowa

Tattini M, Traversi ML (2008) Responses to changes in $\mathrm{Ca}^{2+}$ supply in two Mediterranean evergreens, Phillyrea latifolia and Pistacia lentiscus, during salinity stress and subsequent relief. Ann Bot 102:609-622

Wahid A, Gelani S, Ashraf M, Foolad MR (2007) Review heat tolerance in plants: an overview. Environ Exp Bot 61:199-223

White PJ (2001) The pathways of calcium movement to the xylem. J Exp Bot $52: 891-899$

Zhu JK (2001) Plant salt tolerance. Trend Plant Sci 6:66-71

Zhu JK (2003) Regulation of ion homeostasis under salt stress. Curr Opin Plant Biol 6:441-445

Zocchi G, Mignani I (1995) Calcium physiology and metabolism in fruit trees. Acta Hortic 383:15-23

\section{Publisher's Note}

Springer Nature remains neutral with regard to jurisdictional claims in published maps and institutional affiliations. 